\title{
Epithermal Neutron Activation Analysis of Carbonaceous Chondrites and the Polonnaruwa/ Aralaganwila Stones
}

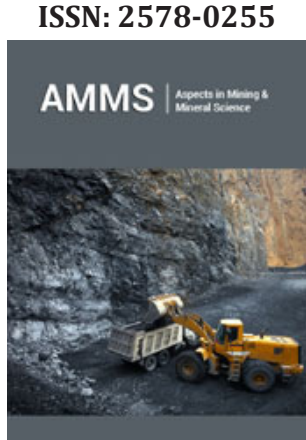

*Corresponding author: Marina Frontasyeva, Frank Laboratory of Neutron Physics, Joint Institute for Nuclear Research, Russian Federation, Russia

Submission: 址 November20, 2020

Published: 監 December 15, 2020

Volume 6 - Issue 1

How to cite this article: Hoover RB, Frontasyeva M, Pavlov S, Epithermal Neutron Activation Analysis of Carbonaceous Chondrites and the Polonnaruwa/Aralaganwila Stones. Aspects Min Miner Sci. 6(1). AMMS. 000626. 2020.

DOI: 10.31031/AMMS.2020.06.000626

Copyright@ Marina Frontasyeva, This article is distributed under the terms of the Creative Commons Attribution 4.0 International License, which permits unrestricted use and redistribution provided that the original author and source are credited.

\author{
Hoover RB ${ }^{1}$, Frontasyeva $\mathbf{M}^{2 *}$ and Pavlov $\mathrm{S}^{2}$ \\ ${ }^{1}$ NASA Marshall Space Flight Center \& United States Space and Rocket Center, USA \\ ${ }_{2}^{2}$ Joint Institute for Nuclear Research, Russian Federation, Russia
}

\begin{abstract}
The results of multi-element epithermal neutron activation analysis of extraterrestrial materialsCarbonaceous Chondrites and the Polonnaruwa/Aralaganwila Stones-are reported. A total of 41 elements were determined at the reactor IBR-2 of the Joint Institute for Nuclear Research in Dubna, Russian Federation. Special emphasis is made on anomalous levels in the Polonnaruwa/Aralaganwila stones of heat-producing elements (HPE's) Potassium (K), Thorium and Uranium and the Rare Earth Elements (REE), as compared with theTh, U, and KREEP component of Lunar basalts and the Orgueil, Murchison, Sutter's Mill and NWA carbonaceous chondrites.
\end{abstract}

Keywords: Carbonaceous chondrites; Polonnaruwa/Aralaganwila stones; Epithermal neutron activation analysis; Elemental content; Rare earth elements; KREEP

Abbreviations: REE: Rare Earth Elements; ENAA: Epithermal Neutron Activation Analysis; JINR: Joint Institute of Nuclear Research; MSFC: Marshall Space Flight Center; IBR-2: Pulsed Fast Reactor; KREEP: K (Potassium); P: Phosphorus; HPEs: Heat-Producing Elements $\left({ }^{40} \mathrm{~K},{ }^{232} \mathrm{Th},{ }^{235} \mathrm{U},{ }^{238} \mathrm{U}\right)$

\section{Introduction}

Carbonaceous chondrites are messengers from Space. Carbonaceous chondrites are classified into nine groups ( $\mathrm{CI}, \mathrm{CM}, \mathrm{CO}, \mathrm{CV}, \mathrm{CR}, \mathrm{CH}, \mathrm{CB}, \mathrm{CK}$ and C-Ungrouped) in accordance with their distinctive compositions reflective of the type of parent body of the stones. By far the most extensively studied carbonaceous chondrites are the Orgueil CI1 and the Murchison CM2 meteorites, both of which were observed falls. Other important carbonaceous meteorites are the NWA finds from the deserts of North West Africa. Carbonaceous chondrites are precious extraterrestrial materials that provide a window into the nucleosynthesis of elements within stars and the origin of our Solar System [1,2]. The CI (Ivuna Type) carbonaceous chondrites are considered the most primitive meteorites since their element abundances (except for Lithium and volatile gases) closely match that of the solar photosphere. They condensed in the cooler outer regions of the proto-solar nebula during the formation of the Solar System and contain nano diamonds, silicon carbide grains and interstellar dust particulates much older than the Sun that were frozen into the ancient ices of the Oort cloud, comets and icy moons of the outer Solar System. Heavy element isotopic studies revealed the Orgueil CI1 meteorite contains SiC grains formed by S-process nucleosynthesis that occurs mainly in Asymptotic Giant Branch (AGB) stars and ancient Red Giants, whereas their SiC type X grains probably formed in supernovae [3-6]. Migration of the giant planets soon after the formation of our Solar System caused gravitational destabilization of the main asteroid belt producing heavy bombardment of the inner planets between 4.48 and 3.8 billion years ago [7-9]. Measurements of impact melt ages in Lunar meteorites and moon rocks returned by the Apollo Astronauts and the Soviet Luna Missions, and shocked minerals formed by high velocity impacts in asteroidal meteorites provides observational evidence for the Lunar Cataclysm Hypothesis [10,11]. Although once controversial, it has now become generally accepted that vast quantities of water, carbon, complex organics and life-critical biomolecules were delivered to early Earth by comets, planetesimals, water-bearing asteroids and carbonaceous meteorites during this period of heavy bombardment.

The CI1 carbonaceous chondrites are micro regolith breccias that are the rarest of all meteorites. The Alais meteorite (the first known carbonaceous chondrite) fell in southern France on March 15, 1806. Thénard [12] noted the Alais CI1 stones were completely different 
from all other meteorites as they contained water and carbon and "looked like solidified clay". The Alais stones disintegrated giving off a clay-like odor when placed in liquid water because they were composed of tiny mineral grains and insoluble organic matter (IOM) globules cemented together by water soluble salts. Only five CI1 carbonaceous chondrites (Alais, Orgueil, Tonk, Ivuna, Revelstoke) are known on Earth. They were all observed falls that were collected soon after they fell before these fragile stones could be destroyed by rainfall. There are also five CI-like carbonaceous chondrites (Y-82162, Y-86029, Y-86737, Y-980115, Y-980134), finds that were cryopreserved in the blue ice fields of the Yamato mountains, Antarctica. When they entered the atmosphere and the duration of their weathering on Earth is unknown, but their mineralogy, petrology and chemical composition is similar to the CI1 carbonaceous chondrites [13].

The Orgueil CI1 meteorite is by far the most extensively documented and thoroughly investigated of all CI1 carbonaceous chondrites. At 8:00 P.M. on the evening of May 14, 1864 a brilliant fireball terrified villagers across a wide region of southern France. The trajectory through the atmosphere was marked by a thin strip of smoke that extended behind the fireball. The Orgueil bolide exploded like a thunderous cannonade and dozens of stones rained down within a $4 \mathrm{~km} \times 20 \mathrm{~km}$ east-west scatter ellipse bounded by the villages of Orgueil ( $43^{\circ} 53^{\prime} \mathrm{N} ; 01^{\circ} 23^{\prime} \mathrm{E}$ ), Campsas, Nohic (Tarnet-Garonne department) and Fronton (Haute-Garonne). The main mass fell near the village of Orgueil ( $\left.43^{\circ} 53^{\prime} \mathrm{N} ; 01^{\circ} 23^{\prime} \mathrm{E}\right)$ and over 20 jet-black stones, many with complete fusion crusts, were collected by villagers immediately after the fall and sent to the leading scientists of France. The CI1 stones are distinguished from other carbonaceous chondrites by a complete absence of chondrules and refractory inclusions (destroyed by extensive low temperature aqueous alteration on the parent body) and by their high content ( 10-20\%) of indigenous extraterrestrial water [13-16]. In 1864, François Cloëz $[17,18]$ the pioneer of analytical chemistry, carried out a microscopic and chemical analysis of the Orgueil meteorite. He discovered the dominant portion of the insoluble carbonaceous matter in Orgueil was a complex insoluble polymeric carbon that had chemical composition similar to ancient organic matter of humic substances, peat, and lignite coal (C 63.45\%; H 5.98\%; $\mathrm{O}$ $30.57 \%$; $\mathrm{O} / \mathrm{C}=0.48$ ) but very different from that of living biological matter (C 6.4\%; H 63\%; 0 26\%; O/C 2 to 10).

Pisani [19] was first to study the mineral composition of Orgueil and to suggest that it contained clay-type minerals such as serpentine. This conclusion has been confirmed by X-ray diffraction studies which revealed the Orgueil phyllosilicates consist of two types of alternating layers. The first (characterized by constant interlayer $\sim 7 \AA$ ) corresponding to a magnesium-rich iron-containing serpentine and the second interlayer (range 10$15 \AA$ ) corresponding to magnesium-rich iron-containing clay minerals of the smectite group such as montmorillonite or saponite [20]. It is now well established that the dominant mineral (62.6 $\%)$ of Orgueil is Chlorite $\left[(\mathrm{Fe}, \mathrm{Mg}, \mathrm{Al})_{6}(\mathrm{Si}, \mathrm{Al})_{4} \mathrm{O}_{10}(\mathrm{OH})_{8}\right]$ of the clay phyllosilicates mineral group . Other major minerals include: $6.7 \%$ Epsomite $\left(\mathrm{MgSO}_{4} .7 \mathrm{H}_{2} \mathrm{O}\right) ; 6 \%$ Magnetite $\left(\mathrm{Fe}_{3} \mathrm{O}_{4}\right) ; 4.6 \%$ Troilite (FeS), $2.9 \%$ gypsum $\left(\mathrm{CaSO}_{4} \cdot \mathrm{nH}_{2} \mathrm{O}\right)$ and $2.8 \%$ Breunnerite $(\mathrm{Fe}, \mathrm{Mg}) \mathrm{CO}_{3}$. Epsomite is the most important evaporite mineral in the stones and it now forms white veins in the stones. However, when the Orgueil stones first fell, Daubrée [21] reported that the interior was "a dark charcoal-colored substance so soft that it could be easily cut with a knife" creating "smooth and shiny surfaces which is an indication of a fine, paste-like matter."

The Murchison CM2 carbonaceous chondrite contains a vast suite of complex organics [22]. A brilliant orange fireball with a silvery rim and dull orange conical tail leaving a blue smoke trail was seen over a wide region of Western Australia at 10:58 AM on September 28, 1969. Loud explosions and tremors were reported as the bolide fragmented into 3 major pieces before dozens of black stones fell in a $1.6 \mathrm{X} 16 \mathrm{~km}$ scatter ellipse around the town of Murchison, Victoria, Australia (36 $37^{\prime} \mathrm{S}, 1^{\circ} 5^{\circ} 14^{\prime} \mathrm{E}$ ). The total weight of the recovered Murchison stones was $4.5 \mathrm{~kg}$ and the main mass recovered was $680.2 \mathrm{~g}$. Over $70 \%$ of the carbon content of the Murchison CM2 carbonaceous chondrite is in the form of a complex kerogen-like macromolecular insoluble organic matter (IOM) of high aromaticity. Schmidt, et al. [23] reported extensive suites of organic molecules in soluble fraction of the Murchison meteorite which exhibited "indigenous chemical diversity to tens of thousands of different molecular compositions and likely millions of diverse structures." Many of the organic molecules found were completely unknown in terrestrial biological systems. Other structures resembled known chiral biomolecules but were considered to result from abiotic synthesis because of their distribution was racemic $(D / L=1)$. However, the phenomena of the racemization of ancient amino acids and other biomolecules is well known and forms the basis for amino acid dating and geochronology [24,25]. Therefore the detection of racemic mixtures of amino acids or other biologically produced molecules could simply indicate they are ancient rather than produced by abiotic mechanisms. Several of the chiral biomolecules found in Orgueil, Murchison and other carbonaceous meteorites exhibit an excess of the L-enantiomer that is much greater that can be produced by any known abiotic production/amplification mechanism, but consistent with ancient life processes [26].

The CI and CM carbonaceous chondrites have been found to contain tetrapyrroles including vanadium porphyrins, pristane, phytane and saturated polyisoprenoid hydrocarbons [27-30]. These molecular fossils are strong biomarkers that are wellknown to petroleum geologists. The distribution of pristane and phytane in the Orgueil stones was found to be similar to that of pre-Cambrian (1.88GYa) microfossil-bearing Gunflint chert. These ancient biomolecules are the biogeochemical degradation products of the chlorophyll molecule. The magnesium chelating tetrapyrrole of the chlorophyll pigment plays a crucial role in the photosynthetic process by harvesting sunlight and converting the energy of photons into chemical energy. Tetrapyrroles are considered the pigments 
of life and they have no known abiotic production mechanisms [31]. The chlorophyll molecule, found in the mesosomes of cyanobacteria and chloroplasts of algae and green plants, is derived from glutamate by a complex branched enzymatic biosynthetic pathway employing a light-harvesting chlorophyll binding protein [32]. Although pristane, phytane and other fossil biomolecules are present in carbonaceous chondrites, there have been no reports of the detection of chlorophyll, magnesium porphyrins of chlorins in these meteorites, providing strong evidence the stones have not been contaminated by recent terrestrial cyanobacteria or other photosynthetic microorganisms.

In 1997, independent Scanning Electron Microscopy investigations of freshly fractured interior surfaces of the Murchison CM2 carbonaceous chondrite were carried out in Russia and in the United States. These studies resulted in the discovery $[33,34]$ of similar microfossils of filamentous cyanobacteria and other microbial remains embedded in rock matrix of the meteorite samples from different sources in Russia and the United States. Subsequently, collaborative studies showed a great diversity of wellpreserved, recognizable microfossils of filamentous cyanobacteria, diatoms, prasinophytes and other microalgae in Murchison (CM2), Orgueil (CI1) and several other groups of carbonaceous chondrites [35-40]. Energy dispersive X-ray Spectroscopy revealed that these clearly biological remains exhibited ratios of essential biogenic element consistent with ancient permineralized or carbonized microfossils rather than recent terrestrial bio-contaminants [41]. The Sutter's Mill CM2 meteorite fireball blazed across the skies of Nevada and California at 7:51 AM on April 22, 2012. A 2 gram fragment of a stone that was collected on April 27 (five days after the fall) was provided to RBH for scientific research. NASA/MSFC Scanning Electron Microscopy studies of freshly fractured interior surfaces of this pristine freshly fallen meteorite fragment yielded images of fossilized cyanobacterial filaments. Energy Dispersive X-Ray Spectroscopy data revealed C/O and C/N ratios of many of these carbon-rich, oxygen-poor filaments were similar in chemical composition to ancient biological matter converted to the insoluble organic material known as kerogen and were therefore considered indigenous.

The Polonnaruwa/Aralaganwila Ungrouped stones are associated with a bright yellow fireball that was seen traveling across the skies of a large region of North Central Sri Lanka at 18:30 on December 29, 2012. The large bolide turned green and fragmented as thunderous explosions were heard and several hundred friable black stones of high porosity rained down around the villages of Polonnaruwa and Aralaganwila. These unusual stones were recovered from the surface of undisturbed sandy soil in well cultivated rice fields and on roads and rooftops. Eyewitness reports from many different locations indicated the trajectory of the fireball was from NE to SW. Observations of the atmospheric trajectory aided in the subsequent discovery of similar stones of somewhat higher density in a strewn field that extended over $40 \mathrm{~km}$ to the western banks of the Ratkinda reservoir and the village of
Girandurukotte, Sri Lanka. The very low-density stones recovered near Aralaganwila immediately after the fall were reported to emit gas and give off an odor "similar to sulfurous asphalt or tar." One woman lost consciousness and was hospitalized after picking up one of these stones. Concerned that the gas might be toxic, the Aralaganwila police officials warned people not to touch the stones but to report the location of any found. Police immediately collected many samples and sent them by courier to Dr. Anil Samaranayake (Director of the Medical Research Institute (MRI) of the Ministry of Health in Colombo, Sri Lanka) to test them for toxic chemical and pathogens. The MRI scientists determined the Polonnaruwa/ Aralaganwila stones contained no dangerous gases, pathogenic bacteria or viruses. However, an MRI microbiologist. Dr. Keerthi Wickramarathne. observed diatoms. Soon thereafter samples in these stones were sent to Prof. N. C. Wickramasinghe at Cardiff University and Prof. Richard B. Hoover for Scanning Electron Microscopy investigations at the NASA/Marshall Space Flight Center and Athens State University These independent studies confirmed that the Polonnaruwa/Aralaganwila stones contained a large suite of exceptionally well-preserved, fossilized remains of recognizable diatoms, cyanobacteria and other microalgae. After joint investigations were conducted at Cardiff University, the research team traveled to Colombo, Sri Lanka to discuss their findings with Dr. Samaranayake and the MRI scientists and to visit the fall site. On January 29, 2013 (one month after the fall), Mr. Tikiri Banda described the trajectory of the fireball as seen from his rice paddy to one of us (RBH). He reported that he watched the fragments falling "like twinkling fireflies" into his field around him. Less than 5 meters from the spot where this interview was being conducted, Hoover observed and collected a fusion encrusted stone (POL_162). The stone was lying on the surface of the dry sandy soil at GPS Waypoint 162 (N 752' 59.5”; E; 81 09' 15.7” E). It was collected without touching it by enveloping it in sterile Aluminum foil. Sand from immediately under the stone (along with possible fusion crust fragments) was collected in a sterile Zip-Lock bag. The team then walked the rice field and recovered several other small Polonnaruwa/Aralaganwila stones. Some of these stones were returned to Cardiff University and others to NASA/MSFC for study. SEM investigations revealed they contained well-preserved fossils of diatoms, cyanobacteria, alveolata, prasinophytes and extinct aquatic life forms such as acritarchs and hystrichospheres, They also contained forms of unknown biological affinity similar to those previously found in the sample CU.PIN 2A that was initially sent to RBH by Dr. Anil Samaranayake of MRI [42]. Other stones found in the field were returned to Cardiff University for physical, chemical and mineralogical investigations. The Polonnaruwa/Aralaganwila stones are dark grey to black in color. They were found to exhibit highly porous poikilitic textures comprising isotropic silica-rich/ plagioclase-like hosts. It was immediately recognized that these extremely fragile dark colored, highly porous, low density $(\sim 0.6 \mathrm{~g} /$ $\mathrm{cm}^{3}$ ) stones were unlike representatives of any of the known groups of meteorites. It was also obvious that they also were unlike known Earth rocks. There are only two rocks known on Earth that 
have density $<1 \mathrm{~g} / \mathrm{cm}^{3}$ such that that they float on water. These are Pummice (light colored porous igneous rock or amorphous volcanic glass formed by explosive volcanic eruptions) and Diatomite (fragile, light-colored sedimentary rock composed of the skeletal remains of diatoms). Mineralogical studies carried out by Dr. Jamie Wallis and Dr. Anthony Oldroyd at the School of Earth and Ocean Sciences, Cardiff University, clearly established the Polonnaruwa/ Aralaganwila stones were dramatically different and exhibited exotic minerals and clear evidence of extreme shocks [43]. The stones contained mm-sized to smaller inclusions and subangular grains of ilmenite, fayalitic olivine, quartz and accessory zircons that were frequently found to be more fractured than the surrounding host. The presence of crystalline phases was determined using X-Ray Diffraction techniques carried out on a Philips PW1710 Automated Powder Diffractometer on five different aliquot samples of the Polonnaruwa, Ratkinda and Girandurukotte stones. The bulk mineral compositions include accessory cristobalite $\left(\mathrm{SiO}_{2}-\right.$ high temperature polymorph of quartz), anorthite - $\left(\mathrm{CaAl}_{2} \mathrm{Si}_{2} \mathrm{O}_{8}-\right.$ rare on Earth but abundant on the Moon); Wüstite-(FeO-found in meteorites); albite - $\left(\mathrm{Na}\left(\mathrm{AlSi}_{3} \mathrm{O}_{8}\right)\right.$; anorthoclase $\left.(\mathrm{Na}, \mathrm{K}) \mathrm{AlSi}_{3} \mathrm{O}_{8}\right)$; and hercynite- $\left(\mathrm{FeAl}_{2} \mathrm{O}_{4}\right.$-found in martian meteorites [43,44]. The minerals anorthite and cristobalite have also been found in the Orgueil (CI1) and Murchison (CM2) carbonaceous meteorites.

The very low density $\left(\sim 0.6 \mathrm{~g} / \mathrm{cm}^{3}\right)$ measured for the extremely porous Polonnaruwa stones is consistent with the values predicted $\left(\sim 0.6 \mathrm{~g} / \mathrm{cm}^{3}\right)$ for the nucleus of comet Halley [45] and measured $\left(\sim 0.62 \mathrm{~g} / \mathrm{cm}^{3}\right)$ for the nucleus of comet 9P/Temple 1 by the Deep Impact Mission [46] The Polonnaruwa/Aralaganwila stones also contained the high pressure phase transformation olivine polymorph Wadsleyite $\left(\alpha-(\mathrm{Mg}, \mathrm{Fe})_{2} \mathrm{SiO}_{4}\right)$, which was first found in the Peace River L6 chondrite [47]. Wadsleyite has also been found in meteorites ejected by impacts on Mars [48]. Wadsleyite is only found on Earth to be stable between $410-520 \mathrm{~km}$ deep where it is a potential host for water in the upper part of the Transition Zone of the Earth's mantle [49]. The presence of Wadsleyite suggests previous endurance of a shock pressure of the order of $20 \mathrm{GPa}$. Further evidence of shock in the Polonnaruwa/Aralaganwila stones is confirmed by the conversion of all plagioclase to Maskelynite, a glassy material formed by explosive shock in meteorites and impact craters [50]. The host matrix chemical compositions vary between samples of the stones. However, all of them are rich in $\mathrm{SiO}_{2}$. The silica-rich melts display a heterogeneous K-enrichment comparable to that found in rare iron meteorites, LL chondritic breccias and Lunar granites. The K-enrichment in shocked isotropic plagioclase results from the fractionation between $\mathrm{K}$ and $\mathrm{Na}$ in the shock veins of L-chondrites. The $\mathrm{Na}$ is not completely lost from the melt veins but incorporated in liquid phase at high temperature/ pressure in majorite-pyrope garnet crystals [51]. A major part of the $\mathrm{K}$ is lost in vapor phase and subsequently scavenged by Maskelynite melt pockets close to the melt veins resulting in K-enrichment. Maskelynite is a clear, glassy pseudomorph of plagioclase that forms by the quenching of dense mineral melts produced by high-pressure shock waves typically of order $\sim 25 \mathrm{GPa}$. The bulk chemical compositions of plagioclase-like samples are comparable to reported data for the Miller Ranger 05035 Lunar meteorite, while the Si-rich samples accord well with mafic and felsic glasses reported in NWA 1664 (Howardite) as well as data for fusion crust present in a variety of meteoritic samples. The silica-rich melts of the Polonnaruwa/Aralaganwila stones display a heterogeneous K-enrichment comparable to that reported in a range of extraterrestrial material from rare iron meteorites to LL chondritic breccias and Lunar granites collected during the Apollo missions [52]. The Lunar granites in particular were characterized by high $\mathrm{SiO}_{2}$ (60 to $74 \mathrm{wt} \%$ ) and $\mathrm{K}_{2} \mathrm{O}$ (2 to $10.4 \mathrm{wt} \%$ ), and low $\mathrm{Na}_{2} \mathrm{O}(0.4$ to $1.9 \mathrm{wt} \%)$. The triple oxygen isotope values for the Polonnaruwa/Aralaganwila stones show $\Delta 170=-0.335$ with $\delta 180$ (\%o rel. SMOW) values of $17.816 \pm 0.100$ which compare well with the CI carbonaceous chondrites and are within the range of CI-like (Meta-C) chondrites but far away from the terrestrial fractionation line which represents the oxygen isotopes in rocks of the Earth and the Moon [53].

These results definitively show that the Aralaganwila/ Polonnaruwa stones are not terrestrial rocks. However, possibly because these extremely low density stones they are unlike all currently known groups of meteorites, they have not yet been validated as meteorites. It is also widely thought that such low density stones could not survive transit through the Earth's atmosphere. However, recent theoretical studies have shown that under appropriate conditions such low-density stones could survive [54]. The OSIRIS REx mission has recently discovered widespread organics across the surface of the low-density, C complex nearEarth asteroid (101955) Bennu that is considered to be similar to CK4 carbonaceous chondrites [55]. Stones with density $<1 \mathrm{~g} / \mathrm{cm}^{3}$ were collected from the surface of the black, low-density rubblepile asteroid during the sampling process [56]. It was noted that these stones are unlike any representatives of any of the known meteorite groups. When the Bennu samples are returned to Earth their physical properties, mineralogy, distribution of elements, organic compounds and possible biogenic remains may resolve the mystery of the Polonnaruwa/Aralaganwila stones.

On Dec. 7, 2020, China's Chang'e-5 Lunar Probe transferred lunar rock and soil samples collected from the Mons Rümker region of Oceanus Procellarum to the re-entry capsule for return to Earth. The Mons Rümker dome is a geochemically anomalous area that overlies the Procellarum KREEP terrain (PKT) of the Moon. KREEP is an acronym for samples of lunar material containing very high concentrations of incompatible elements: Potassium K, REE (rareearth elements) and phosphorus P that were returned by the NASA Apollo 15 and Apollo 17 Missions [57]. The Mons Rümker region is characterized by anomalously high concentrations of Rare Earth Elements (REE) and Heat-Producing Elements (HPEs) thorium, uranium and potassium [58-61]. These elements have radioactive isotopes with extremely long half-lives $\left({ }^{232} \mathrm{Th}-1.41 \times 10^{10} \mathrm{yr}\right.$; ${ }^{235} \mathrm{U}-7.1 \times 10^{8} \mathrm{yr},{ }^{238} \mathrm{U},-4.51 \times 10^{9} \mathrm{yr} ; 40 \mathrm{~K}-1.251 \times 10^{9} \mathrm{yr}$ ) that they are important to the current production of heat in planets and planetesimals [58,59]. Thorium, $\mathrm{U}$, and $\mathrm{K}$ are highly incompatible elements because their crystal/melt coefficients are far less than 1 , 
hence they are concentrated in melts rather than residues during partial melting.)

The Polonnaruwa stones have been found to contain many minerals and fractured grains present in meteorites, including minerals such as Wadsleyite and Maskelynite that are formed only under conditions of extreme pressure or great shock [43]. These stones also contain extremely high levels of Thorium, Uranium, and Potassium such as found in the Lunar KREEP basalts and the Mons Rümker dome. The Polonnaruwa/Aralaganwila stones are clearly very different from all known terrestrial rocks, but they are also unlike all other representatives of known groups of meteorites. The extensive array of exceptionally well-preserved fossils of diatoms, cyanobacteria, acritarches and other aquatic microalgae found in these stones clearly establish that at some point in time liquid water was present on the parent body [42]. The samples returned from the near-Earth from asteroid (101955) Bennu and the Mons Rümker dome may provide new insights into the nature and origin of these exotic ungrouped meteorites. The presence of ancient microfossils in Orgueil, Murchison, Polonnaruwa/Aralaganwila and other carbonaceous chondrites [33-42] may also hold vital clues to the Origin of Life on Earth as well as to the distribution of Biospheres throughout the Cosmos.

Neutron activation analysis (NAA) was selected as the most appropriate technique for the determination of the relatively low abundance levels for trace elements in chondrites, and a method was devised to determine these elements simultaneously. In 1964, Lovering and Morgan used NAA to make a simultaneous determination of the abundances of Uranium and Thorium in the Orgueil CI1, Mokoia CV3 and the Karoonda CK4 carbonaceous chondrites and the Hvittis enstatite chondrite, providing data in support of the Hoyle theory of nucleosynthesis of elements within stars [1-4]. Neutron Activation Analysis being a technique based on a physical principle different from those of other trace element techniques became widely used for quantification of trace elements at ultra-low levels starting from late 1970's [62,63] while studying the elemental content of Moon rocks and extraterrestrial materials. Additional possibilities became apparent by the introduction of activation with epithermal neutrons (ENAA) [64-68]. This allows better determination of Rare Earth Elements due to their large resonance integrals in the epithermal interval of neutron energies. For the first time instrumental ENAA was applied for the determination of elemental content of falls of CI1 and CM2 Carbonaceous Chondrites and the and C-Ungrouped Polonnaruwa/ Aralaganwila stones as well as the finds (NWA 5515 CK4; NWA 6136 C03; NWA 2086 CV3; NWA 4549 C03.5) from Northwest Africa. The purpose of this study was to utilize ENAA to obtain precise data concerning the distribution of diverse elements and element ratios in selected falls and finds of different groups of carbonaceous chondrites for comparison with elements and element ratios of the exotic ungrouped Polonnaruwa/Aralaganwila stones.

\section{Materials and Methods}

\section{Sampling and sample preparation for ENAA}

The dried samples were ground into fine powder in an agate ball mill. Two sub-samples of each sample were heat-sealed in polyethylene foil bags for short-term irradiation long-term irradiation were packed in aluminum cups. The samples of the meteorites used in this study were around 100mg each, both for short- and long irradiation.

\section{Epithermal neutron activation analysis (ENAA)}

The analytical procedures and the basic characteristics of the employed pneumatic system at the IBR-2M reactor are described in detail elsewhere $[67,68]$. Two types of irradiation were carried out. One is a short irradiation for 2 min to determine short-lived isotopes ( $\mathrm{Al}, \mathrm{Ca}, \mathrm{Cl}, \mathrm{I}, \mathrm{Cu}, \mathrm{Mg}, \mathrm{Mn}, \mathrm{Si}, \mathrm{Ti}$, and $\mathrm{V}$ ). After a decay-period of $5-7 \mathrm{~min}$ the irradiated samples were measured twice, first for 3-5 min and then for 10-15min. A long-irradiation of 4-5 days was used to analyze for long-lived radionuclides. After irradiation, the samples were re-packed and measured twice: first after $\sim 100$ $\mathrm{h}$ for $40-50 \mathrm{~min}$ to determine As, $\mathrm{Br}, \mathrm{K}, \mathrm{La}, \mathrm{Na}, \mathrm{Mo}, \mathrm{Sm}, \mathrm{U}$, and $\mathrm{W}$ and after 20 days for 2.5-3 hours to determine $\mathrm{Ba}, \mathrm{Ce}, \mathrm{Co}, \mathrm{Cr}, \mathrm{Cs}$, $\mathrm{Fe}, \mathrm{Hf}, \mathrm{Ni}, \mathrm{Rb}, \mathrm{Sb}, \mathrm{Sc}, \mathrm{Sr}, \mathrm{Ta}, \mathrm{Tb}, \mathrm{Th}, \mathrm{Yb}$, and $\mathrm{Zn}$. The gamma spectra of induced activity were measured with a high-purity germanium (HPGe) detector (Canberra) with a resolution of $1.9 \mathrm{keV}$ for the 60Co $1332 \mathrm{keV}$ line. The processing of spectra data and calculation of elemental concentrations were performed using Genie2000 and software developed in FLNP, JINR [69]. Certified reference materials and flux comparators were used to determine the concentrations of elements by relative method of calculations.

\section{Quality control of ENAA}

In order to evaluate the precision and accuracy of the results, the certified reference materials and standards were used, namely NIST SRM 1633b-Constituent Elements in Coal Fly Ash, NIST SRM1632c- Trace Elements in Coal (Bituminous), IRMM SRM 667-Estuarine Sediment, NIST SRM 2711-Montana Soil, NIST SRM 2710-Montana Soil, NIST SRM 1547-Peach Leaves, NIST SRM 1575a-Trace Elements in Pine Needles, 2891-copper concentrate (Russia), and Ir was prepared as a liquid standard. (Table 1) shows the differences between certified and calculated values of concentrations, where "SRM" were used as standards for calculations of concentrations for SRMs in the columns "Sample". Most differences between certified and obtained values are lower than $2 \sigma$ but for Sc, Sm, and U the relative differences are $20-27 \%$. There are no such data for elements Tb, Yb, Ta, Dy, W, Re, Ir because their certified value are in the irradiated SRM only.

Table 1: ENAA-obtained and certified values of reference materials, mg/kg.

\begin{tabular}{|c|c|c|c|c|c|c|c|c|c|}
\hline SRM & Sample & Element & Obtained & Certified & SRM & Sample & Element & Obtained & Certified \\
\hline 667 & $1632 \mathrm{c}$ & $\mathrm{Na}$ & $324 \pm 16$ & $298.8 \pm 4.8$ & & & As & $15.7 \pm 2.7$ & $17.1 \pm 2.8$ \\
\hline 1547 & $1575 \mathrm{a}$ & $\mathrm{Mg}$ & $1184 \pm 213$ & $1060 \pm 170$ & 2711 & 667 & Se & $1.76 \pm 0.33$ & $1.52 \pm 0.14$ \\
\hline
\end{tabular}




\begin{tabular}{|c|c|c|c|c|c|c|c|c|c|}
\hline $1633 \mathrm{~b}$ & 1547 & $\mathrm{Al}$ & $240 \pm 10$ & $249 \pm 8$ & 667 & 2711 & $\mathrm{Br}$ & $20.5 \pm 1.0$ & $18.7 \pm 0.4$ \\
\hline $1575 \mathrm{a}$ & 1547 & $\mathrm{Cl}$ & $411 \pm 33$ & $360 \pm 19$ & 667 & $1632 \mathrm{c}$ & $\mathrm{Rb}$ & $147 \pm 52$ & $110 \pm \mathrm{n} / \mathrm{c}$ \\
\hline 2711 & $1632 \mathrm{c}$ & $\mathrm{K}$ & $835 \pm 169$ & $1100 \pm 33.0$ & $1632 \mathrm{c}$ & 2711 & $\mathrm{Sr}$ & $53.6 \pm 5.9$ & $63.8 \pm 1.4$ \\
\hline 1547 & $1633 \mathrm{~b}$ & $\mathrm{Ca}$ & $14800 \pm 1420$ & $15100 \pm 604$ & 2711 & $1632 \mathrm{c}$ & $\mathrm{Sb}$ & $19.8 \pm 1.4$ & $19.4 \pm 1.8$ \\
\hline 667 & $1632 \mathrm{c}$ & $\mathrm{Sc}$ & $2.33 \pm 0.14$ & $2.905 \pm 0.036$ & 667 & 2711 & $\mathrm{Cs}$ & $0.485 \pm 0.05$ & $0.594 \pm 0.01$ \\
\hline $1633 \mathrm{~b}$ & 2710 & $\mathrm{Ti}$ & $2724 \pm 354$ & $2830 \pm 100$ & 667 & $1632 \mathrm{c}$ & $\mathrm{Ba}$ & $867 \pm 95$ & $726 \pm 38$ \\
\hline $1633 \mathrm{~b}$ & 1547 & $\mathrm{~V}$ & $0.38 \pm 0.04$ & $0.37 \pm 0.03$ & $1632 \mathrm{c}$ & 667 & $\mathrm{La}$ & $35.5 \pm 11$ & $40 \pm \mathrm{n} / \mathrm{c}$ \\
\hline $1632 \mathrm{c}$ & 667 & $\mathrm{Cr}$ & $147 \pm 13.4$ & $178 \pm 16.0$ & $1632 \mathrm{c}$ & 2711 & $\mathrm{Ce}$ & $9.5 \pm 1.3$ & $11.9 \pm 0.2$ \\
\hline 2710 & $1575 \mathrm{a}$ & $\mathrm{Mn}$ & $503 \pm 25$ & $488 \pm 12$ & 667 & 2711 & $\mathrm{Sm}$ & $0.779 \pm 0.06$ & $1.078 \pm 0.028$ \\
\hline 667 & 2711 & $\mathrm{Fe}$ & $27220 \pm 1361$ & $28900 \pm 1734$ & 667 & $1632 \mathrm{c}$ & $\mathrm{Eu}$ & $0.089 \pm 0.036$ & $0.1238 \pm 0.0033$ \\
\hline 667 & $1632 \mathrm{c}$ & $\mathrm{Co}$ & $3.41 \pm 0.2$ & $3.48 \pm 0.2$ & 667 & $1632 \mathrm{c}$ & $\mathrm{Hf}$ & $11.6 \pm 3.5$ & $7.3 \pm \mathrm{n} / \mathrm{c}$ \\
\hline 667 & 2711 & $\mathrm{Ni}$ & $19.6 \pm 2.0$ & $20.6 \pm 1.1$ & $1632 \mathrm{c}$ & 2711 & $\mathrm{Th}$ & $1.32 \pm 0.07$ & $1.4 \pm 0.03$ \\
\hline 2710 & 1572 & $\mathrm{Cu}$ & $14.8 \pm 5.3$ & $16.5 \pm 1.0$ & 667 & $1632 \mathrm{c}$ & $\mathrm{U}$ & $0.372 \pm 0.03$ & $0.513 \pm 0.012$ \\
\hline 667 & 2711 & $\mathrm{Zn}$ & $332.8 \pm 26.5$ & $350.4 \pm 13.0$ & 667 & $1632 \mathrm{c}$ & & \\
\hline
\end{tabular}

\section{Results and Discussion}

The epithermal neutron activation analysis results are provided for the concentration of 41 elements as measured in the various samples of the carbonaceous chondrites belonging to different meteorite groups. (Table 2) provides the ENAA data for the Carbonaceous Chondrite Falls and (Table 3) provides data for the Finds investigated by ENAA. (Table 4) shows measurements of Uranium and Thorium in the samples and the U/Th ratios. The samples include the Orgueil CI1; Murchison CM2; Sutter's Mill CM2 meteorites for comparison with results obtained for the exotic Polonnaruwa/Aralaganwila stones that are very different from all known groups of meteorites and terrestrial rocks and which are as yet unclassified and Ungrouped some seven years after the witnessed fall. These black, low-density Polonnaruwa/Aralaganwila stones are associated with the brilliant fragmenting fireball that was observed over a wide area of North Central Sri Lanka on Dec. 29, 2012. Some complete stones with fusion crust and many fragments (some with partial fusion crust) were recovered immediately after the fall. Other stones that exhibit similar microfossil assemblages and physical/chemical characteristics were collected from a $40 \mathrm{~km}$ scatter ellipse a month or more after the fall. The low-albedo Polonnaruwa/Aralaganwila stones are very friable and of such low density that they float in water. However, unlike Alais, Orgueil and the other CI1 carbonaceous chondrites, the Polonnaruwa/ Araganwila stones are not micro-regolith breccias and they do not disintegrate when placed in liquid water or when exposed to rainfall.

Table 2: Concentrations of major and trace elements in extraterrestrial materials "Falls", mg/kg. Errors are given in \%.

\begin{tabular}{|c|c|c|c|c|c|c|c|c|c|c|c|c|c|c|}
\hline FALLS & $\begin{array}{c}\mathrm{Na} \\
(3 \%)\end{array}$ & $\begin{array}{c}\mathrm{Mg} \\
(6 \%)\end{array}$ & $\begin{array}{c}\mathrm{Al} \\
(2 \%)\end{array}$ & \multicolumn{2}{|c|}{$\begin{array}{c}\mathrm{Si} \\
(20 \%)\end{array}$} & $\begin{array}{c}\mathrm{Cl} \\
(10 \%)\end{array}$ & K (5\%) & $\begin{array}{c}\mathrm{Ca} \\
(7 \%)\end{array}$ & $\begin{array}{c}\text { Sc } \\
(5 \%)\end{array}$ & $\begin{array}{c}\mathrm{Ti} \\
(8 \%)\end{array}$ & V (3\%) & $\begin{array}{c}\mathrm{Cr} \\
(12 \%)\end{array}$ & $\begin{array}{c}\text { Mn } \\
(2 \%)\end{array}$ & $\begin{array}{c}\mathrm{Fe} \\
(5 \%)\end{array}$ \\
\hline Orgueil - CI1 MHNP6 & 7440 & 167000 & 10400 & \multicolumn{2}{|c|}{61900} & 1100 & $<600$ & 12700 & 6.49 & $\begin{array}{l}507 \\
(13) \\
\end{array}$ & 62.6 & 2700 & 2070 & 208000 \\
\hline Murchison - CM2 & 6180 & 185000 & 12500 & \multicolumn{2}{|c|}{75300} & 643 & $<600$ & 19100 & 7.75 & $757(9)$ & 76.8 & 2680 & 1750 & 211000 \\
\hline Sutter's Mill - CM2 & 6360 & 204000 & 14700 & \multicolumn{2}{|c|}{119000} & 355 & $<600$ & 23100 & 8.48 & $\begin{array}{l}894 \\
(12)\end{array}$ & 81.6 & 3030 & 1960 & 249000 \\
\hline $\begin{array}{l}\text { POL-RBH-141 Aralag- } \\
\text { anwila }\end{array}$ & 8510 & 24000 & 6640 & \multicolumn{2}{|c|}{178000} & 1680 & 138000 & 46300 & $\begin{array}{l}0.39 \\
(10)\end{array}$ & $\begin{array}{l}957 \\
(26)\end{array}$ & $<1$ & 45.3 & 7560 & 5660 \\
\hline $\begin{array}{c}\text { POL_Banda_Cu.PIN } \\
\text { 2a } \\
\text { Aralaganwila-MRI }\end{array}$ & 1220 & 40400 & 4680 & \multicolumn{2}{|c|}{198000} & 1720 & 130000 & 60800 & $\begin{array}{c}0.165 \\
(10)\end{array}$ & $<30$ & 3.05 (18) & 15.2 & 10900 & 2080 \\
\hline $\begin{array}{c}\text { POL-RBH_162 } \\
\text { Aralaganwila Interior }\end{array}$ & 2450 & 46000 & 6230 & \multicolumn{2}{|c|}{111000} & $\begin{array}{l}179 \\
(18)\end{array}$ & 132000 & 64300 & 2.86 & 4490 & 82 & 27.2 & 8770 & 80500 \\
\hline $\begin{array}{l}\text { SAND Under POL-162 } \\
\text { at WayPoint } 162\end{array}$ & 7870 & 21700 & 54200 & \multicolumn{2}{|c|}{232000} & $\begin{array}{l}54.8 \\
(25)\end{array}$ & 38300 & 4980 & 2.01 & 2750 & 24.1 & 23.8 & 200 & 7520 \\
\hline \multicolumn{2}{|l|}{ FALLS } & $\begin{array}{c}\text { Co } \\
(6 \%)\end{array}$ & $\begin{array}{c}\mathrm{Ni} \\
(9 \%)\end{array}$ & $\begin{array}{c}\mathrm{Cu} \\
(30 \%)\end{array}$ & $\begin{array}{r}\mathrm{Zn} \\
(3 \%\end{array}$ & \begin{tabular}{c|c} 
Ga \\
$(30 \%)$
\end{tabular} & $\begin{array}{c}\text { As } \\
(8 \%)\end{array}$ & $\begin{array}{c}\mathrm{Se} \\
(9 \%)\end{array}$ & $\begin{array}{c}\mathrm{Br} \\
(4 \%)\end{array}$ & $\begin{array}{c}\mathbf{R b} \\
(20 \%)\end{array}$ & $\begin{array}{c}\mathrm{Sr} \\
(7 \%)\end{array}$ & $\begin{array}{c}\text { Sb } \\
(15 \%)\end{array}$ & $\begin{array}{c}\text { Cs } \\
(20 \%)\end{array}$ & $\begin{array}{c}\mathrm{Ba} \\
(6 \%)\end{array}$ \\
\hline Orgueil - CI1 MHNF & & 527 & 9620 & 204 & 387 & 13.2 & 2.06 & 33.5 & 7.13 & 3.14 & 45.9 & 0.15 & 0.22 & 8.8 \\
\hline
\end{tabular}




\begin{tabular}{|c|c|c|c|c|c|c|c|c|c|c|c|c|c|}
\hline Murchison - CM2 & 548 & 11200 & 211 & 211 & $<3$ & 1.86 & 17.7 & 7.28 & 3.57 & 43.4 & 0.091 & 0.05 & 5.9 \\
\hline Sutter's Mill - CM2 & 629 & 13100 & 225 & 213 & $<3$ & 2.15 & 19 & 4.07 & 3.33 & 77.7 & 0.12 & 0.21 & 10.3 \\
\hline $\begin{array}{l}\text { POL-RBH-141 Aralaganwi- } \\
\text { la/Fusion Crust }\end{array}$ & 11.3 & 50.4 & $<30$ & 175 & 10.7 & $<0.03$ & $<0.1$ & 2.44 & 439 & 183 & 0.11 & 0.41 & 2110 \\
\hline $\begin{array}{l}\text { POL_Banda_Cu.PIN 2a } \\
\text { Aralaganwila-MRI }\end{array}$ & 10.1 & 19.3 & 190 & 81.4 & $<3$ & 0.22 & $<0.1$ & 2.19 & 323 & 172 & $\begin{array}{c}0.014 \\
(22)\end{array}$ & 0.29 & 1740 \\
\hline $\begin{array}{c}\text { Pol-RBH-162 } \\
\text { Aralaganwila Interior }\end{array}$ & 17.1 & $\begin{array}{l}13.5 \\
(12)\end{array}$ & 279 & 47.3 & 12 & $\begin{array}{l}0.09 \\
(17)\end{array}$ & $\begin{array}{l}0.26 \\
(40)\end{array}$ & 0.6 & 378 & 219 & 0.033 & 0.52 & 2140 \\
\hline $\begin{array}{c}\text { SAND Under POL-162 at } \\
\text { WayPoint } 162\end{array}$ & 3.65 & 19.3 & $<30$ & $\begin{array}{l}10.2 \\
(7)\end{array}$ & 8.85 & 0.3 & $<0.1$ & 1.1 & 158 & 97.7 & 0.032 & 0.75 & 3.4 \\
\hline
\end{tabular}

\begin{tabular}{|c|c|c|c|c|c|c|c|c|c|c|c|c|c|c|c|}
\hline FALLS & $\begin{array}{c}\text { La } \\
(10 \%)\end{array}$ & $\begin{array}{c}\mathrm{Ce} \\
(10 \%)\end{array}$ & $\begin{array}{c}\text { Nd } \\
(10 \%)\end{array}$ & $\begin{array}{c}\text { Eu } \\
(20 \%)\end{array}$ & $\begin{array}{l}\mathrm{Sm} \\
(7 \%)\end{array}$ & $\begin{array}{c}\text { Tb } \\
(20 \%)\end{array}$ & $\begin{array}{c}\mathrm{Yb} \\
(25 \%)\end{array}$ & $\begin{array}{c}\operatorname{Tm} \\
(20 \%)\end{array}$ & $\begin{array}{c}\text { Hf } \\
(15 \%)\end{array}$ & $\begin{array}{c}\text { Ta } \\
(17 \%)\end{array}$ & $\begin{array}{c}\mathrm{Re} \\
(12 \%)\end{array}$ & $\begin{array}{c}\text { Ir } \\
(40 \%)\end{array}$ & $\begin{array}{c}\mathrm{Au} \\
(30 \%)\end{array}$ & $\begin{array}{c}\text { Th } \\
(7 \%)\end{array}$ & $\begin{array}{c}U \\
(10 \%)\end{array}$ \\
\hline $\begin{array}{l}\text { Orgue- } \\
\text { il - CI1 } \\
\text { MHNP6 }\end{array}$ & 0.25 & 2.86 & 2.08 & 0.19 & 0.16 & 0.036 & 0.22 & 0.07 & 0.23 & 0.016 & 0.28 & 198 & 0.25 & 0.049 & 0.009 \\
\hline $\begin{array}{l}\text { Murchi- } \\
\text { son - CM2 }\end{array}$ & 0.35 & 2.49 & 1.76 & 0.11 & 0.2 & 0.055 & 0.24 & 0.092 & 0.2 & $\begin{array}{c}0.0112 \\
(30)\end{array}$ & 0.29 & 236 & 0.26 & 0.042 & 0.008 \\
\hline $\begin{array}{l}\text { Sutter's } \\
\text { Mill - CM2 }\end{array}$ & 0.36 & 4.47 & 3.06 & 0.36 & 0.22 & 0.067 & 0.4 & 0.1 & 0.36 & 0.036 & 0.48 & 255 & 0.3 & 0.073 & 0.031 \\
\hline $\begin{array}{c}\text { POL- } \\
\text { RBH-141 } \\
\text { Aralag- } \\
\text { anwila/ } \\
\text { Fusion } \\
\text { Crust }\end{array}$ & 0.47 & 3.47 & 34.4 & 0.27 & 0.11 & 0.024 & 0.29 & 0.14 & 0.95 & 0.017 & 3.47 & 35 & $\begin{array}{l}0.00 \\
353\end{array}$ & 0.143 & 0.023 \\
\hline $\begin{array}{l}\text { POL_Ban- } \\
\text { da_- } \\
\text { Cu.PIN 2a } \\
\text { Aralagan- } \\
\text { wila-MRI }\end{array}$ & 1.38 & 3.15 & 24.1 & 0.07 & 0.17 & 0.018 & 0.1 & 0.063 & 0.11 & 0.005 & 4.41 & $<0.6$ & $\begin{array}{c}0.000 \\
429\end{array}$ & 0.135 & 0.043 \\
\hline $\begin{array}{c}\text { Pol- } \\
\text { RBH-162 - } \\
\text { Aralagan- } \\
\text { wila }\end{array}$ & 8.65 & 23.2 & 31.8 & 0.09 & 0.85 & 0.087 & 0.13 & 0.055 & 5.08 & 0.14 & 4.02 & $<0,6$ & $\begin{array}{c}0.000 \\
311\end{array}$ & 2.33 & 0.39 \\
\hline $\begin{array}{c}\text { SAND Un- } \\
\text { der POL- } \\
162 \text { at } \\
\text { WayPoint } \\
162\end{array}$ & 6.46 & 13.7 & 13.7 & 0.08 & 0.93 & 0.163 & 0.87 & 0.12 & 8.98 & 0.19 & 1.55 & 1.4 & 0.0009 & 3.11 & 1.06 \\
\hline
\end{tabular}

Table 3: Concentrations of major and trace elements in extraterrestrial materials "Finds", mg/kg. Errors are given in \%.

\begin{tabular}{|c|c|c|c|c|c|c|c|c|c|c|c|c|c|}
\hline FINDS & $\begin{array}{c}\mathrm{Na} \\
(3 \%)\end{array}$ & $\begin{array}{c}\mathrm{Mg} \\
(6 \%)\end{array}$ & $\begin{array}{c}\mathrm{Al} \\
(2 \%)\end{array}$ & $\begin{array}{c}\mathbf{S i} \\
(20 \%)\end{array}$ & $\begin{array}{c}\mathrm{Cl} \\
(10 \%)\end{array}$ & $\begin{array}{c}\mathrm{K} \\
(5 \%)\end{array}$ & $\begin{array}{c}\mathrm{Ca} \\
(7 \%)\end{array}$ & $\begin{array}{c}\text { Sc } \\
(5 \%)\end{array}$ & $\begin{array}{c}\mathrm{Ti} \\
(8 \%)\end{array}$ & V (3\%) & $\operatorname{Cr}(12 \%)$ & $\begin{array}{l}\text { Mn } \\
(2 \%)\end{array}$ & $\begin{array}{c}\mathrm{Fe} \\
(5 \%)\end{array}$ \\
\hline NWA 5515-CK4 & 2330 & 237000 & 17200 & 89600 & $\begin{array}{l}118 \\
(21)\end{array}$ & $<600$ & 28800 & 7.61 & 1090 & 118 & 2630 & 1670 & 181000 \\
\hline NWA 6136-CO3 & 3450 & 227000 & 14800 & 83700 & 587 & $<600$ & 21700 & 14.1 & 840 & 93.3 & 3380 & 1650 & 246000 \\
\hline $\begin{array}{l}\text { NWA 4540- } \\
\quad \text { C03.5 }\end{array}$ & 3340 & 186000 & 14100 & 109000 & 764 & $<600$ & 24600 & 5.06 & 956 & 82.9 & 1750 & 1530 & 134000 \\
\hline NWA 2086- CV3 & 2080 & 205000 & 14700 & 84500 & 410 & $<600$ & 23500 & 9.53 & 751 & 90.5 & 3500 & 1320 & 274000 \\
\hline
\end{tabular}




\begin{tabular}{|c|c|c|c|c|c|c|c|c|c|c|c|c|c|}
\hline FINDS & $\begin{array}{c}\text { Co } \\
(6 \%)\end{array}$ & $\begin{array}{c}\mathrm{Ni} \\
(9 \%)\end{array}$ & $\begin{array}{c}\mathrm{Cu} \\
(30 \%)\end{array}$ & $\begin{array}{c}\mathrm{Zn} \\
(3 \%)\end{array}$ & $\begin{array}{c}\text { Ga } \\
(30 \%)\end{array}$ & $\begin{array}{c}\text { As } \\
(8 \%)\end{array}$ & $\begin{array}{c}\mathrm{Se} \\
(9 \%)\end{array}$ & $\begin{array}{c}\mathrm{Br} \\
(4 \%)\end{array}$ & $\begin{array}{c}\mathbf{R b} \\
(20 \%)\end{array}$ & $\begin{array}{c}\mathrm{Sr} \\
(7 \%)\end{array}$ & $\begin{array}{c}\text { Sb } \\
(15 \%)\end{array}$ & $\begin{array}{c}\text { Cs } \\
(20 \%)\end{array}$ & $\begin{array}{c}\mathrm{Ba} \\
(6 \%)\end{array}$ \\
\hline NWA 5515- CK4 & 268 & 2050 & 128 & 94.8 & $<3$ & 6.24 & 2.5 & 0.53 & 0.98 & 19.9 & 0.051 & 0.05 & 233 \\
\hline NWA 6136- CO3 & 592 & 11300 & 140 & 94.3 & 6.95 & 2.26 & 13.1 & 1.08 & $<0.5$ & 48.8 & 0.082 & 0.12 & 7.9 \\
\hline NWA 4540- C03.5 & 345 & 7050 & 102 & 63.6 & 10.3 & 2.85 & 5.61 & 2.96 & $<0.5$ & 38.8 & 0.056 & 0.11 & 287 \\
\hline NWA 2086- CV3 & 340 & 3370 & 138 & 128 & 6.87 & 2.58 & 8.49 & 1.37 & 1.86 & 26.2 & 0.1 & 0.062 & 73.6 \\
\hline
\end{tabular}

\begin{tabular}{|c|c|c|c|c|c|c|c|c|c|c|c|c|c|c|c|}
\hline FINDS & $\begin{array}{c}\text { La } \\
(10 \%)\end{array}$ & $\begin{array}{c}\mathrm{Ce} \\
(10 \%)\end{array}$ & $\begin{array}{c}\text { Nd } \\
(10 \%)\end{array}$ & $\begin{array}{c}\text { Eu } \\
(20 \%)\end{array}$ & $\begin{array}{c}\text { Sm } \\
(7 \%)\end{array}$ & $\begin{array}{c}\text { Tb } \\
(20 \%)\end{array}$ & $\begin{array}{c}\mathrm{Yb} \\
(25 \%)\end{array}$ & $\begin{array}{c}\mathrm{Tm} \\
(20 \%)\end{array}$ & $\begin{array}{c}\text { Hf } \\
(15 \%)\end{array}$ & $\begin{array}{c}\text { Ta } \\
(17 \%)\end{array}$ & $\begin{array}{c}\operatorname{Re} \\
(12 \%)\end{array}$ & $\begin{array}{c}\text { Ir } \\
(40 \%)\end{array}$ & $\begin{array}{c}\mathrm{Au} \\
(30 \%)\end{array}$ & $\begin{array}{c}\text { Th } \\
\text { (7\%) }\end{array}$ & $\begin{array}{c}\mathrm{U} \\
(10 \%)\end{array}$ \\
\hline $\begin{array}{c}\text { NWA } \\
5515- \\
\text { CK4 }\end{array}$ & 0.59 & 2.46 & 0.96 & 0.11 & 0.24 & 0.053 & 0.23 & 0.055 & 0.16 & 0.019 & 0.18 & 247 & 0.035 & 0.065 & 0.11 \\
\hline $\begin{array}{c}\text { NWA } \\
6136- \\
\text { C03 }\end{array}$ & 0.39 & 4.33 & 1.56 & 0.46 & 0.24 & 0.069 & 0.28 & 0.092 & 0.27 & 0.047 & 0.082 & 274 & 0.3 & 0.045 & 0.018 \\
\hline $\begin{array}{c}\text { NWA } \\
4540- \\
\text { C03.5 }\end{array}$ & 0.57 & 2.11 & 1.16 & 0.13 & 0.28 & 0.015 & 0.19 & 0.05 & 0.17 & 0.017 & 0.42 & 149 & 0.16 & 0.033 & 0.1 \\
\hline $\begin{array}{c}\text { NWA } \\
2086- \\
\text { CV3 }\end{array}$ & 0.55 & 3.2 & 1.22 & 0.1 & 0.26 & 0.074 & 0.38 & 0.054 & 0.24 & 0.033 & 0.17 & 323 & 0.12 & 0.0384 & 0.49 \\
\hline
\end{tabular}

Table 4: Concentrations of Thorium and Uranium $(\mathrm{mg} / \mathrm{kg})$ and their ratio.

\begin{tabular}{|c|c|c|c|}
\hline Name of Extraterrestrial Material & Th & $\mathbf{U}$ & Th / U \\
\hline \multicolumn{4}{|l|}{ FALLS } \\
\hline Orgueil-CI1 MHNP6 & 0.049 & 0.009 & 5.4 \\
\hline Murchison CM2 & 0.042 & 0.008 & 5.25 \\
\hline Sutter's Mill CM2 & 0.073 & 0.014 & 5.21 \\
\hline POL-RBH-141 Aralaganwila/Fusion Crust & 0.047 & 0.023 & 2.04 \\
\hline $\begin{array}{l}\text { POL_Banda_Cu.PIN 2a } \\
\text { Aralaganwila-MRI }\end{array}$ & 0.025 & 0.004 & 6.25 \\
\hline POL-RBH-162 Aralaganwila & 2.33 & 0.39 & 5.97 \\
\hline Sand Under POL-RBH-162 at WayPoint 162 & 0.015 & 0.007 & 2.14 \\
\hline \multicolumn{4}{|l|}{ FINDS } \\
\hline NWA 5515 CK4 & 0.019 & 0.004 & 4.75 \\
\hline NWA 6136 CO-3 & 0.045 & 0.006 & 7.5 \\
\hline NWA 2086 CV3 & 0.028 & 0.007 & 4 \\
\hline NWA 4540 C03.5 & 0.033 & 0.012 & 2.75 \\
\hline
\end{tabular}

The samples of Falls used in this study were:

a. Orgueil CI1: Vial $(\sim 0.2 \mathrm{~g})$ from Orgueil meteorite MHNP6 sample from Musée Nationale d'Histoire Naturelle, Paris provided to Richard B. Hoover in June, 2005 for research. (Courtesy Dr. Martine Rossignol-Strick).

b. Murchison CM2: Fragment $(\sim 0.5 \mathrm{~g})$ from Registration No, E12393 sample of Melbourne, Australia Museum Victoria Meteorite Collection provided to Richard B. Hoover in 1998 for research. (Courtesy Dr. William Birch).

c. Sutter's Mill CM2: Fragment ( $\sim 0.1 \mathrm{~g})$ from $11.6 \mathrm{~g}$ specimen SM65 collected by Philip Deriemer and provided by Michael Farmer for scientific research (Courtesy Michael Farmer Meteorites). d. POL_RBH_141: Small Aralaganwila/Polonnaruwa stone with partial fusion crust collected at Waypoint 141 by Richard B. Hoover Collection Jan. 29, 2013.

e. POL_Banda_Cu.PIN2a: Fragment of stone collected by rice farmer, Tikiri Banda in his rice paddy field in Aralaganwila, Sri Lanka within an hour or two after he observed the stones to fall "like twinkling fireflies". This stone was sent to the Medical Research Institute in Colombo, Sri Lanka for chemical and microbiological tests to evaluate possible toxicity or pathogenicity. After diatoms were observed, Dr. Anil Samaranayake, sent a 10 gram interior fragment of the Banda stone to RBH for Scanning Electron Microscopy studies at NASA/MSFC and at Athens State University. Small fragments of this stone were then taken to Cardiff University 
for studies by Drs. Wickramasinghe, Wallis and Oldroyd and to Moscow for collaborative Scanning Electron Microscopy studies with Academician Alexei Yu. Rozanov at the Paleontological Institute (PIN/RAS) . Other fragments of this stone were prepared at PIN/ RAS to polished thin sections for transmission optical microscopy and mineralogical analysis. (Courtesy Anil Samarnayake).

f. POL_RBH_162: Interior fragment $(0.5 \mathrm{~g})$ of the stone collected on Jan. 29, 2013 at 4:00 PM at waypoint 162 (N $7^{\circ} 52^{\prime}$ 59.5”; E; 81 09' 15.7" E) during interview with Tikiri Banda in a rice paddy field near Aralaganwila, Sri Lanka.

g. SAND under POL_RBH_162: Sand collected using sterile materials under low-density black stone at waypoint 162-possibly containing fusion crust fragments.

(Table 3) provides the samples of Finds used in this ENAA study:

\section{h. NWA 5515 CK4 Algeria, Nov., 2007 [70] \\ i. NWA 6136 CO3 Morocco, 2008 [71] \\ j. NWA 2086 CV3 Purchase Rissani [72] \\ k. NWA 4540 C03.5 NorthWest Africa, 2006 [73]}

(Table 4) shows that the Polonnaruwa/Aralaganwila have Th/U ratios that are quite similar to the other falls, with the exception of sample POL_RBH_141 fusion crust. Additional studies are needed to determine if this effect is due to contamination of the fusion crust with terrestrial sand or an affect of alteration during atmospheric entry. However several of the other elements exhibit dramatic differences. The results of this ENAA analysis of the carbonaceous chondrites with respect to the Polonnaruwa/Aralaganwila stones are most intriguing. (Tables 2 \& 3) reveal Polonnaruwa/ Aralaganwila concentrations are similar for some elements but very different in other elements from other groups of the Carbonaceous Chondrites. The Polonnaruwa/Aralaganwila stones concentration deficit is more than an order of magnitude for $\mathrm{Mg}$ and $\mathrm{Cr}$ and over two orders of magnitude for $\mathrm{Au}$ and $\mathrm{Ni}$. The excess of Re is greater by an order of magnitude and the $\mathrm{Rb}, \mathrm{Ba}$ and $\mathrm{K}$ excess is more than two orders of magnitude greater than the other carbonaceous chondrites studied.

\section{Conclusion}

The ENAA data on the 41 elements clearly reveal dramatic differences in element concentrations of the Polonnaruwa/ Aralaganwila stones as compared to the Carbonaceous Chondrites. It is very clear that these stones are very different from representatives of several major groups of carbonaceous meteorites. The Rhenium excess is very interesting. Rhenium is a heavy, third-row transition metal in group 7 of the periodic table with atomic number 75 . It is one of the rarest elements in the Earth's crust with an estimated average concentration of 1 part per billion (ppb). The unusual concentrations of Rhenium and other elements provides additional support to the previous Oxygen Isotope and mineralogy data establishing that the Polonnaruwa/ Aralaganwila stones are not terrestrial rocks. While the $\mathrm{Th} / \mathrm{U}$ ratios of the Polonnaruwa/Aralaganwila stones are not dramatically different from the other carbonaceous chondrites studied, the content of the heat-producing elements Thorium (Th-2.33mg/kg) and Uranium (U-0.39mg/kg) in sample POL-RBH-162 Aralaganwila is astonishingly high. The level of Potassium (K>130,000mg/kg) in all of the Polonnaruwa/Aralaganwila stones is vastly greater than that measured for the other meteorites in this investigation. More extensive ENAA investigations of different samples of the Polonnaruwa/Aralaganwila stones along with the Ratkinda and Girandurukotte samples and a variety of other carbonaceous meteorites may provide additional important information to provide answers to these intriguing mysteries.

\section{Acknowledgement}

We thank Dr. Martine Rossignol-Strick Musée Nationale d'Histoire Naturelle for Orgueil samples; Dr. William Birch Museum Victoria Meteorite Collection for Murchison samples; Dr. Michael Farmer for Sutter's Mill samples and Dr. Paul Sipiera Planetary Studies Foundation for NWA samples. We thank Brig Klyce Astrobiology Research Trust; Gregory Jerman \& James Coston NASA Marshall Space Flight Center and Dr. George Williams, Athens State University for funding and Scanning Electron Microscopy support. We are very grateful to Dr. N. Chandra Wickramasinghe, Dr. Jamie Wallis, Dr. Daryl H. Wallis, Dr. Nori Miyake of Cardiff University for scientific support. We thank Dr. Anil Samaranayake and Dr. Keerthi Wickramaranthe and Mr. Tikiri Banda for their kind assistance during our field Expedition to Polonnaruwa and Aralaganwila, Sri Lanka. Special thanks are also due to Academician Alexei Yu. Rozanov, A. K. Ryumin, M. I. Kapralov and E. A. Saprykin, Astrobiology Centre, JINR and PIN, RAS for Scanning Electron Microscopy and Paleontological support.

\section{References}

1. Hoyle F (1946) The synthesis of the elements from hydrogen. Mon Not Roy Astr Soc 106: 343-383.

2. Hoyle F, Fowler WA (1964) On the abundances of uranium and thorium in solar system material. In: Craig H, Miller S, Wasserburg GJ (Eds.), Isotopic and Cosmic Chemistry. North Holland Publishing Company, Amsterdam, Netherlands. pp. 516-529.

3. Lovering JF, Morgan JW (1964) Uranium and thorium abundances in stony meteorites. 1 . The chondritic meteorites. J Geophys Res 69(10): 1979-1988.

4. Burbidge EM, Burbidge GR, Fowler WA, Hoyle F (1957) Synthesis of the elements in stars. Rev Mod Phys 29(4): 547-650.

5. Nguyen AN, Messenger S (2011) Presolar history recorded in extraterrestrial materials. Elements 7(1): 17-22.

6. Heck PR, Greer J, Kööp L, Trappitsch R, Gyngard F, et al. (2020) Lifetimes of interstellar dust from cosmic ray exposure ages of presolar silicon carbide. Proc Nat Acad Sci 117: 1884-1889.

7. Kring DA, Cohen BA (2002) Cataclysmic bombardment throughout the inner solar system 3.9-4.0 Gyr. J Geophys Res 107(2): 4-11.

8. Gomes R, Levison HF, Tsiganis K, Morbidelli A (2005) Origin of the cataclysmic late heavy bombardment period of the terrestrial planets. Nature 435(7041): 466-469.

9. Mojzsis SJ, Brasser R, Kelly NM, Abramov O, Werner SC (2019) Onset of giant planet migration before 4480 million years ago. Astrophys J 881(1): 1-13. 
10. Cohen BA, Swindle TD, Kring DA (2000) Support for the lunar cataclysm hypothesis from lunar meteorite impact melt ages. Science 290(5497): 1754-1756.

11. Marchi S, Bottke WF, Cohen BA, Wünnemann K, Kring DA, et al. (2013) High-velocity collisions from the lunar cataclysm recorded in asteroidal meteorites. Nature Geoscience 6(4): 303-307.

12. Thénard LJ (1806) Analysis of a fireball that fell from Alais district. Ann Chim Phys 59: 103-110.

13. King AJ, Solomon JR, Schofield PF, Russell SS (2015) Characterising the CI and CI-like carbonaceous chondrites using thermogravimetric analysis and infrared spectroscopy. Earth, Planets and Space 67(198): 1-12.

14. Endress M, Bischoff A (1993) Mineralogy, degree of brecciation, and aqueous alteration of the CI chondrites Orgueil, Ivuna and Alais. Meteoritics 28(3): 345-346.

15. Endress M, Bischoff A (1996) Carbonates in CI chondrites: Clues to parent body evolution. Geochim Cosmochim Acta 60(3): 489-507.

16. Endress M, Spettel B, Bischoff A (1994) Chemistry, petrology, and mineralogy of the Tonk CI1 chondrite: Preliminary results. Meteoritics 29(4): 462-463.

17. Cloëz S (1864) Note sur la composition chimique de la pierre météorique d Orgueil. Compt Rend Acad Sci, Paris 58: 986-988.

18. Cloëz S (1864) Analyse chimique de la pierre météorique d Orgueil. Note de M S Cloëz presentée par M Daubrée Compt Rend Acad Sci 59: 37-40.

19. Pisani F (1864) Étude chimique et analyse de laerolithe d Orgueil. Compt Rend Acad Sci 59: 132-135.

20. Bass MN (1990) Montmorillonite and serpentine in Orgueil meteorite. Geochim et Cosmochim Acta 35: 139-147.

21. Daubrée GA (1864) Communication de M Daubrée, d après sa correspondance et celle de M Le Verrier. Compt Rend Acad Sci 58: 932 937.

22. Sephton MA (2002) Organic compounds in carbonaceous meteorites. Natural Product Reports 19: 292-311.

23. Schmitt Kopplin P, Gabelica Z, Gougeon RD, Fekete A, Kanawati B, et al. (2010) High molecular diversity of extraterrestrial organic matter in Murchison meteorite revealed 40 years after its fall. Proc Nat Acad Sci 107(7): 2763-2768.

24. Bada JL (1985) Amino acid racemization dating of fossil bones. Ann Rev Earth and Planet Sci 13(1): 241-268.

25. Kaufman D, Miller G (1992) Overview of amino acid geochronology. Comparative Biochemistry and Physiology B 102(2): 199-204.

26. Hoover RB (2010) Chiral biomarkers and microfossils in carbonaceous meteorites. Proc SPIE 7819: 03-15.

27. Oró J, Nooner DW, Zlatkiz A, Wikstrom SA (1966) Paraffinic hydrocarbons in the Orgueil, Murray, Mokoia and other meteorites. Life Sciences Space Research 4: 63-100.

28. Oró J, Gelpi E (1969) Gas-chromatographic mass-spectrometric studies on the isoprenoids and other isomeric alkanes in meteorites. In: Meteorite Research. In: Millman PM (Ed.), Springer, Germany. pp.518523.

29. Hodgson GW, Baker BL (1964) Evidence for porphyrins in the Orgueil meteorite. Nature 202(4928): 125-131.

30. Hodgson GW, Baker BL (1969) Porphyrins in meteorites: metal complexes in Orgueil, Murray, Cold Bokkeveld and Mokoia carbonaceous chondrites. Geochim Cosmochim Acta 33(8): 943-958.

31. Battersby AR (2000) Tetrapyrroles: The pigments of life. Nat Prod Rep 17: 507-526.
32. Tanaka R, Rothbart M, Oka S, Takabayashi A, Takahashi K, et al. (2010) LIL3, a light-harvesting-like protein, plays an essential role in chlorophyll and tocopherol biosynthesis. Proc Natl Acad Sci USA 107(38): 1672116725.

33.Zhmur SI, Rozanov A Yu, Gorlenko VM (1997) Lithified remnants of microorganisms in carbonaceous chondrites. Geochemistry International 35: 58-60.

34. Hoover RB (1997) Meteorites, microfossils and exobiology. Proc SPIE 3111: 115-136.

35. Rozanov A Yu, Hoover RB (2004) Atlas of bacteriomorphs in carbonaceous chondrites. Proc SPIE 5163: 23-35.

36. Hoover RB, Rozanov A Yu, Jerman G, Costen J (2004) Microfossils in CI and CO carbonaceous meteorites. Proc SPIE 5163: 7-22.

37. Hoover RB (2011) Fossils of cyanobacteria in CI1 carbonaceous meteorites: Implications to life on comets, europa, and enceladus. Journal of Cosmology 13(35): 3811-3848.

38. Astafieva MM, Geptner AR, Gerasimenko LM, Zhegallo EA, Zhmur SI, et al. (2011) Fossil bacteria and other microorganisms in terrestrial rocks and astromaterials. In: Rozanov A Yu, Ushatinskaya GT (Eds.), pp. 1-172.

39. Hoover RB, Rozanov A Yu, Krasavin EA, Ryumin AK, Kapralov MI (2018) Diatoms in the orgueil meteorite. Paleontological Journal 52(13): 16471650.

40. Rozanov A Yu, Hoover RB, Krasavin EA, Samyilina OS, Ryumin AK, et al. (2020) The orgueil meteorite (Atlas of Microfossils): pp. 1-128.

41. Hoover RB (2007) Ratios of biogenic elements for distinguishing recent from fossil microorganisms. Proc SPIE 6694: 1-20.

42. Hoover RB, Wallis J, Wickramarathne K, Samaranayake A, Williams G, et al. (2013) Fossilized diatoms in meteorites from recent falls in Sri Lanka. Proc SPIE 8965: 1-14.

43. Wallis J, Wickramasinghe $\mathrm{NC}$, Wallis $\mathrm{DH}$, Miyake N, Wallis MK, et al. (2013) Physical, chemical, and mineral properties of the Polonnaruwa stones. Proc SPIE 8865-08: 1-24.

44. Rubin AE (1997) Mineralogy of meteorite groups. Meteoritics \& Planetary Science 32(2): 231-247.

45. Sagdeev RZ, Elyasberg PE, Moroz VI (1988) Is the nucleus of comet Halley a low density body? Nature 331: 240-242.

46. Britt DT, Consolmagno GJ, Merline WJ (2006) Small body density: New data, new insights. Lunar and Planetary Science XXXVII.

47. Price GD, Putnis A, Agrell So, Smith DGW (1983) Wadsleyite, natural $\beta-(\mathrm{Mg}, \mathrm{Fe})_{2} \mathrm{SiO}_{4}$ from the Peace River meteorite. Canadian Mineralogist 21(1): 29-35.

48. Van De Moortèle B, Reynard B, McMillan PF, Wilson M, Beck P, et al. (2007) Shock-induced transformation of olivine to a new metastable $(\mathrm{Mg}, \mathrm{Fe})_{2} \mathrm{SiO}_{4}$ polymorph in Martian meteorites. Earth and Planetary Letters 261(3-4): 469-475.

49. Smyth JR (1987) $\beta-\mathrm{Mg}_{2} \mathrm{SiO}_{4}$ : A potential host for water in the mantle? American Mineralogist 72: 1051-1055.

50. Milton DJ, de Carli PS (1963) Maskelynite: Formation by explosive shock. Science 140(3567): 670-671.

51. Chen M, El Goresy A (2000) The nature of maskelynite in shocked meteorites: not diaplectic glass but a glass quenched from shockinduced dense melt at high pressures. Earth and Planetary Science Letters 179(3-4): 489-502.

52. Papike JJ, Ryder G, Shearer CK (1998) Lunar Samples. In: Papike JJ (Ed.), Reviews in Mineralogy. Planetary Materials 36: Mineralogical Society of America, Washington, USA. pp. 1-5. 
53. Franchi JA, Wright IP, Sexton AS, Pillinger CT (1999) The oxygen isotope composition of Earth and Mars. Meteoritics and Planetary Science 34(4): 657-661.

54. Wickramasinghe NC, Wallis J, Wallis DH, Wallis MK, Miyake N, et al. (2013) Incidence of low density meteoroids of the Polonnaruwa-Type. Journal of Cosmology 22(1): 1-8.

55. Simon AA, Kaplan HH, Hamilton VE, Lauretta DS, Campins H, et al. (2020) Widespread carbon-bearing materials on near-Earth asteroid (101955) Bennu. Science 370 (6517): eabc3522.

56. Scheeres DJ, French AS, Tricarico P, Chesley SR, Takahashi Y, et al. (2020) Heterogeneous mass distribution of the rubble-pile asteroid (101955) Bennu. Sci Adv 6(41): eabc3350.

57. Warren PH, Wasson JT (1979) The origin of KREEP. Rev Geophys Res 17(1): 73-88.

58. Haskin LA (1998) The Imbrium impact event and the thorium distribution at the lunar highlands surface. Journal of Geophysical Research 103(1): 1679-1689.

59. Qian YQ, Xiao L, Zhao SY, Zhao JN, Huang J, et al. (2018) Geology and scientific significance of the Rümker region in northern Oceanus Procellarum: China's Chang'E-5 landing region. J Geophys Res-Planets 123(6): 1407-1430.

60. O’Neill HS (2016) Heat-Producing Elements (HPEs). In: White W (eds) Encyclopedia of Geochemistry. Encyclopedia of Earth Sciences Series. Springer, Germany.

61. Bea F (1998) Elements: Heat-producing. In: Geochemistry. Encyclopedia of Earth Science. Springer, Germany.

62. Brunfelt AO, Steinnes E (1969) Instrumental activation analysis of silicate rocks with epithermal neutrons. Anal Chim Acta 48(1): 13-24.

63. Brunfelt AO, Steinnes E (1971) A neutron-activation scheme developed for the determination of 42 elements in lunar material. Talanta 18(12): 1197-1208.
64. Brunfelt AO, Steinnes E (1973) Determination of rare earths in silicate rocks by epithermal neutron activation and a simple group separation. Jour Radioanalytical Chem 13: 11-20.

65. Morrison GH, Gerard JT, Kashuba AT, Gangadharam EV, Rothenberg AM, et al. (1970) Elemental abundances of lunar soil and rocks. Proceedings of the Apollo 11 Lunar Science Conferencem 2: 1383-1392.

66. Nakamura N (1974) Determination of REE, Ba, Fe, Mg, Na and K in carbonaceous and ordinary chondrites. Geochim et Cosmochim Acta 38(5): 757-775.

67. Frontasyeva MV (2011) Neutron activation analysis for the Life Sciences. A review. Physics of Particles and Nuclei 42(2): 332-378.

68. Frontasyeva MV, Pavlov SS (2005) Scientific reviews: Radioanalytical investigations at the IBR-2 Reactor in Dubna. Neutron News 16(3): 2427.

69. Pavlov SS, Dmitriev A Yu, Chepurchenko IA, Frontasyeva MV (2014) Automation system for measurement of gamma-ray spectra of induced activity for neutron activation analysis at the reactor IBRr-2 of Frank Laboratory of Neutron Physics at the Joint Institute for Nuclear Research. Physics of Elementary Particles and Nuclei 11(6): 737-742.

70. Weisberg MK, Smith C, Benedix G, Herd CDK, Righter K, et al. (2009) The meteoritical bulletin, No. 96, September 2009. Meteoritics \& Planetary Science 44(9): 1355-1397.

71. Garvie LAJ (2012) The meteoritical bulletin, No. 99. pp. 1-52.

72. Rusell SS, Zolensky M, Righter K, Folco L, Jones R, et al. (2005) The meteoritical bulletin, No. 89, 2005 September. Meteoritics \& Planetary Science 40(9): A201-A263.

73. Weisberg MK, Smith C, Benedix G, Folco L, Righter K, et al. (2008) The meteoritical bulletin, No. 94, September 2008. Meteoritics \& Planetary Science 43(9): 1551-1588. 